Article

\title{
Carbonization and Preparation of Nitrogen-Doped Porous Carbon Materials from Zn-MOF and Its Applications
}

\author{
Kulandaivel Sivasankar ${ }^{1, *(\mathbb{D})}$, Souvik Pal ${ }^{2, *}$, Murugan Thiruppathi ${ }^{3(\mathbb{D})}$ and Chia-Her Lin ${ }^{2, *} \mathbb{C}$ \\ 1 Department of Chemistry, Chung-Yuan Christian University, Chungli District, Taoyuan City 32023, Taiwan \\ 2 Department of Chemistry, National Taiwan Normal University, Taipei 11677, Taiwan \\ 3 Department of Biochemical Science and Technology, National Taiwan University, Taipei 10617, Taiwan; \\ thiru9095@gmail.com \\ * Correspondence: sivasankarmpm@gmail.com (K.S.); souvikchem@ntnu.edu.tw (S.P.); \\ chiaher@ntnu.edu.tw (C.-H.L.); Tel.: +886-2-77346221 (C.-H.L.); Fax: +886-2-29324249 (C.-H.L.)
}

Received: 26 November 2019; Accepted: 3 January 2020; Published: 7 January 2020

\begin{abstract}
Nitrogen-doped porous carbon (NPC) materials were successfully synthesized via a Zn-containing metal-organic framework (Zn-MOF). The resulting NPC materials are characterized using various physicochemical techniques which indicated that the NPC materials obtained at different carbonization temperatures exhibited different properties. Pristine MOF morphology and pore size are retained after carbonization at particular temperatures $\left(600{ }^{\circ} \mathrm{C}-\mathrm{NPC}_{600}\right.$ and $\left.800{ }^{\circ} \mathrm{C}-\mathrm{NPC}_{800}\right)$. $\mathrm{NPC}_{800}$ material shows an excellent surface area $1192 \mathrm{~m}^{2} / \mathrm{g}$, total pore volume $0.92 \mathrm{~cm}^{3} / \mathrm{g}$ and displays a higher $\mathrm{CO}_{2}$ uptake $4.71 \mathrm{mmol} / \mathrm{g}$ at $273 \mathrm{k}$ and 1 bar. Furthermore, $\mathrm{NPC}_{600}$ material displays good electrochemical sensing towards $\mathrm{H}_{2} \mathrm{O}_{2}$. Under optimized conditions, our sensor exhibited a wide linearity range between $100 \mu \mathrm{M}$ and $10 \mathrm{mM}$ with a detection limit of $27.5 \mu \mathrm{M}$.
\end{abstract}

Keywords: metal-organic framework; nitrogen-doped porous carbon; carbonization; tuning pore size; $\mathrm{CO}_{2}$ capture; $\mathrm{H}_{2} \mathrm{O}_{2}$ electrochemical sensor

\section{Introduction}

Porous carbon materials have been regarded as significant porous materials because of their distinctive properties such as pore size, extraordinary surface area and good electrochemical activities [1-3]. They have extensive applications in many fields including catalysis, biosensors, fuel cells and supercapacitors [4-11]. In this sense, 3D porous carbon-based structures are promising to numerous applications, such as contamination removal, gas sorption/separation, and electrode materials $[2,12,13]$. In particular, $\mathrm{CO}_{2}$ capture purpose nitrogen-doped porous carbon (NPC) materials were used, because of its stability, low cost and performance [14,15]. For $\mathrm{CO}_{2}$ capture, the pore size of porous material plays a significant role, ultramicropores of $\sim 4 \AA$ to $\sim 8 \AA$ are predominantly suitable for $\mathrm{CO}_{2}$ sorption [16,17]. The preparation of porous carbon materials has been synthesized in a known way such as template and activation method $[18,19]$. Generally, template progression devours a larger quantity of organic or inorganic template and the synthesizing processes are complicated. Activation methods such as $\mathrm{KOH}$ and $\mathrm{NaOH}$ can afford a high surface area but needed a huge amount of activation agents. To avoid such complication, recently metal-organic framework (MOF) materials have gained tremendous attentions to prepare the porous carbon materials through single step carbonization method. For instance, the recently reported porous carbon material derived from $\mathrm{Zn}-\mathrm{MOF}$, having ultramicropore size $\left(\sim 4 \AA\right.$ to $\sim 8 \AA$ ) showed excellent $\mathrm{CO}_{2}$ capture properties [20]. Since MOFs have gained tremendous attention due to their diverse structures with tunable pore shapes, sizes, volumes, and surface chemistry. Therefore, MOFs have prospective applications in gas storage/separation, 
electronic devices, chemical sensors, catalysis, and biomedical applications [21-26]. The multifunctional MOFs are often chosen to synthesis porous carbon materials; MOF-templated straightforward synthesis provided the high-quality nanoporous carbon with a well-ordered pore size and significant surface area. The morphology of nanoporous carbon can be tuned by optimizing the carbonization method (such as temperature, time, and atmosphere) $[1,27,28]$. Recently, MOF-derived metal/metal oxide embedded porous carbon materials [29,30] are used in the electrodes for electrochemical sensors [31,32]. But, maintaining the pristine MOF morphology of the resulting porous materials from the carbonization process is a difficult task due to the shrinkage of framework/decomposing organic ligand during carbonization, therefore, a systematic study is necessary [33].

Additionally, hydrogen peroxide $\left(\mathrm{H}_{2} \mathrm{O}_{2}\right)$ is a toxic oxidizing agent, being used in various fields such as biomedical science, environmental science, food, textile and chemical industries [34-36]. Therefore, $\mathrm{H}_{2} \mathrm{O}_{2}$ determination is of practical importance for both environmental and industrial purposes. It has been well established that $\mathrm{Zn}$ based material modified electrodes are used for $\mathrm{H}_{2} \mathrm{O}_{2}$ detection $[37,38]$.

Therefore, herein, we reported the preparation of NPC materials from $\left\{\mathrm{Zn}_{2}(\mathrm{BDC})_{2}(\mathrm{DABCO})\right\}$ (Zn-MOF) [11] at various temperatures under a $\mathrm{N}_{2}$ atmosphere (Scheme 1). The properties of the resulting NPC materials such as morphology, pore size, pore-volume, $\mathrm{CO}_{2}$ uptake and $\mathrm{H}_{2} \mathrm{O}_{2}$ electrochemical sensing were investigated.

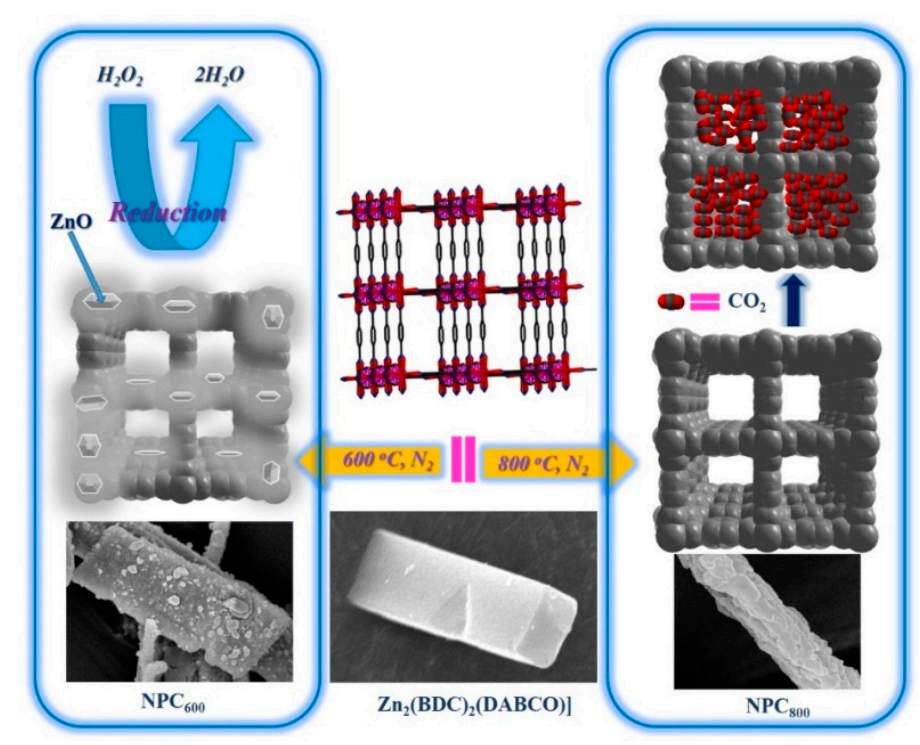

Scheme 1. Synthesizing pathway of NPC materials from Zn-MOF.

\section{Methods}

\subsection{Materials}

$\mathrm{Zn}\left(\mathrm{NO}_{3}\right)_{2} \cdot 6 \mathrm{H}_{2} \mathrm{O},(98 \%)$ and $\mathrm{H}_{2} \mathrm{BDC},(98 \%)$ were bought from Sigma-Aldrich (Burlington, MA, USA), DMF, ( $\geq 99.8 \%$ ) was purchased from Merck (Darmstdt, Germany), (DABCO, 98\%) was purchased from Alfa Aesar (Lancashire, UK). All other compounds used throughout this study were of an analytical grade. The electrochemical experiments were performed using a three-electrode system-CHI model 824B workstation with a screen printed carbon electrode (SPCE)/chemically modified SPCE as a working electrode, $\mathrm{Ag} / \mathrm{AgCl}$ (in $3 \mathrm{M} \mathrm{KCl}$ ) as a reference electrode, and $\mathrm{Pt}$ wire as an auxiliary electrode. SPCE was purchased from Zensor R\&D (Taichung, Taiwan). A phosphate buffer solution (0.1 M, pH 7 PBS) was prepared by mixing $0.1 \mathrm{M}, \mathrm{NaH}_{2} \mathrm{PO}_{4}$, and $\mathrm{Na}_{2} \mathrm{HPO}_{4}$. To compare the various electrodes performance, $5 \mathrm{mM}$ of FeCN solution used as a probe. Briefly, the FeCN solution was prepared using 
$5 \mathrm{mM}$ of $\mathrm{K}_{3}\left[\mathrm{Fe}(\mathrm{CN})_{6}\right]$ and $\mathrm{K}_{4}\left[\mathrm{Fe}(\mathrm{CN})_{6}\right]$, and $0.1 \mathrm{M}, \mathrm{KCl}$ used as a supporting electrolyte. $\mathrm{For}_{2} \mathrm{H}_{2}$ detection, $100 \mathrm{mM}$ of $\mathrm{H}_{2} \mathrm{O}_{2}$ prepared from $9.8 \mathrm{M}$ of $\mathrm{H}_{2} \mathrm{O}_{2}(30 \mathrm{wt} \%)$.

\subsection{Preparation of $\mathrm{Zn}-\mathrm{MOF},\left\{\mathrm{Zn}_{2}(B D C)_{2}(\mathrm{DABCO})\right\}$}

The $\mathrm{Zn}-\mathrm{MOF}$ was prepared [39] by, a mixture of $\mathrm{Zn}\left(\mathrm{NO}_{3}\right)_{2} \cdot 6 \mathrm{H}_{2} \mathrm{O}$ (5.41 mmol, $\left.1.609 \mathrm{~g}\right), \mathrm{H}_{2} \mathrm{BDC}$ $(5 \mathrm{mmol}, 0.83 \mathrm{~g}), \mathrm{DABCO}(2.5 \mathrm{mmol}, 0.28 \mathrm{~g})$ in DMF $(60 \mathrm{~mL})$ was taken out into a Teflon-lined autoclave and heated to $120^{\circ} \mathrm{C}, 2$ days later cooling down to room temperature. The Zn-MOF was washed with DMF and dried at room temperature overnight. Further this material was used for the carbonization process.

\subsection{Preparation of NPC Materials}

The NPC materials were prepared through a single-step carbonization method [31]. The $0.400 \mathrm{~g}$ of $\mathrm{Zn}-\mathrm{MOF}$ was transferred into a silica crucible boat and then placed in a furnace chamber. The NPC materials obtained at target temperatures $\left(500,550,600,700,800\right.$, or $\left.900{ }^{\circ} \mathrm{C}\right)$ under an $\mathrm{N}_{2}$ atmosphere for a $5 \mathrm{~h}$ duration. The resulting materials obtained at $500,550,600,700,800$, and $900{ }^{\circ} \mathrm{C}$ are assigned as $\mathrm{NPC}_{500}, \mathrm{NPC}_{550}, \mathrm{NPC}_{600}, \mathrm{NPC}_{700}, \mathrm{NPC}_{800}$ and $\mathrm{NPC}_{900}$ respectively.

\subsection{Electrode Preparation}

Prior to electrode modification, the bare SPCE was precleaned electrochemically by potential cycling between -1 and $+1 \mathrm{~V}$ vs. $\mathrm{Ag} / \mathrm{AgCl}$ for 6 cycles in $0.1 \mathrm{M} \mathrm{pH} 7 \mathrm{PBS}$. $\mathrm{NPC}_{\mathrm{T}}$ modified SPCE $\left(\mathrm{SPCE} / \mathrm{NPC}_{\mathrm{T}}\right)$ was prepared by the following procedure: $10 \mu \mathrm{L}$ of $2000 \mathrm{ppm}\left(2 \mathrm{mg} \mathrm{mL}^{-1}\right)$ respective $\mathrm{NPC}_{\mathrm{T}}$ dispersed in acetonitrile suspension was drop coated on precleaned SPCE, and allowed for dry on the hot plate at $40{ }^{\circ} \mathrm{C}$ for $15 \mathrm{~min}$. The $\mathrm{NPC}_{\mathrm{T}}$ prepared by carbonization under the increasing temperature of 500, 550, 600, 700, 800 and $900{ }^{\circ} \mathrm{C}$. The corresponding modified electrode designated as $\mathrm{SPCE} / \mathrm{NPC}_{500}, \mathrm{SPCE}_{\mathrm{NPC}}{ }_{550}, \mathrm{SPCE}_{\mathrm{NPC}} \mathrm{N}_{600}, \mathrm{SPCE}_{\mathrm{NPC}} \mathrm{N00}, \mathrm{SPCE} / \mathrm{NPC}_{800}, \mathrm{SPCE}_{\mathrm{NPC}} \mathrm{N}_{90}$, respectively.

\subsection{Characterization}

The purity of MOF and NPC materials were investigated by powder x-ray diffraction (PXRD) using a Bruker D8 advance instrument (Billerica, MA, USA) equipped with $\mathrm{CuK} \alpha$ radiation $(\lambda=1.54178$ $\AA)$. The morphology of MOF and NPC materials were observed by high-resolution scanning electron microscopy (HR-SEM, JEOL JEM-7600F instrument, Akishima, Japan). The NPC materials morphology was characterized by transmission electron microscopy (TEM, using a JEM-2010 instrument, Tokyo, Japan) at a voltage of $200 \mathrm{KV}$. The synthesized NPC materials were also recorded with a Raman spectra on a CCD detector (Stanford Computer Optics Inc., Berkeley, CA, USA) using a He-Ne laser with an excitation wavelength of $632.8 \mathrm{~nm}$. The $\mathrm{Zn}$ element presence was investigated by inductively coupled plasma-mass spectrometry (ICP-MS, Japan Agilent 7500ce, Tokyo, Japan). The elemental analysis (C, $\mathrm{N}, \mathrm{O}$ ) was executed by an elementar vario EL III CHN-OS elemental analyzer (Germany). $\mathrm{N}_{2}$ gas adsorption, $\mathrm{CO}_{2}$ gas adsorption of all materials were measured using micrometrics (Norcross, GA, USA) and the gas sorption analysis purpose, the materials were dried at $120^{\circ} \mathrm{C}$ for $12 \mathrm{~h}$ under vacuum.

\section{Results and Discussion}

\subsection{Structure, Morphology, and Composition of NPC Materials}

Synthesized Zn-MOF structure and porous properties was checked by PXRD, SEM and $\mathrm{N}_{2}$ gas sorption measurements (Figure 1a-d). As expected, the synthesized MOF showed a well-defined crystallinity and surface area of $1700 \mathrm{~m}^{2} / \mathrm{g}$, and good agreement with the literature [40]. The pore size of Zn-MOF was calculated by the NLDFT method, it reveals two micropores (0.75 and $1.4 \mathrm{~nm})$ (Figure 1d). The SEM images revealed the particle shapes of Zn-MOF was a mixture of the cube, brick, and rod-like shapes (Figure 2c). 

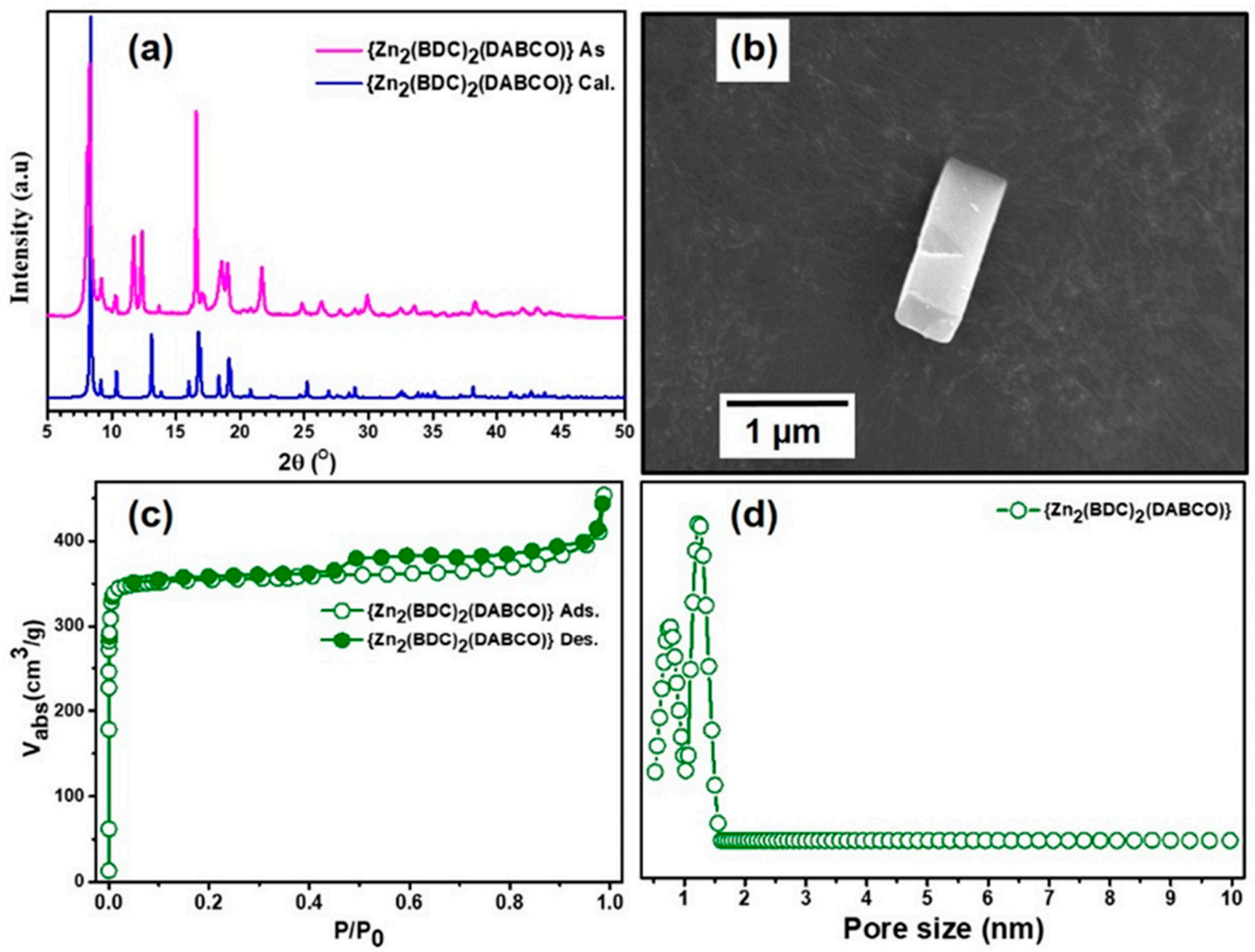

Figure 1. (a) PXRD patterns of as-synthesized Zn-MOF, (b) SEM image of Zn-MOF (c) $\mathrm{N}_{2}$ sorption analysis and (d) NLDFT pore size distribution profile.

The MOF was further exploited to a one-step direct carbonization method to produce the NPC materials. The detailed preparation method is given in Section 2.3. The morphology, crystallinity and surface area of NPC materials were examined by PXRD, SEM, TEM, Raman analysis, $\mathrm{N}_{2}$ gas sorption isotherms, ICP-MS, and elemental analysis.

The PXRD patterns of the $\mathrm{NPC}_{500-700}$ samples showed the diffraction peaks for the formation of $\mathrm{ZnO}$ nanoparticle (Figure 2a). The $2^{\circ}$ peaks at 31.7 (100), 34.4 (002), 36.2 (101), 47.4 (102), 56.6 (110), 62.9 (103), 65.5 (200), 68.0 (112) and 69.1 (201) that are lattice planes of $\mathrm{ZnO}$ [41]. The $\mathrm{NPC}_{500}$, $\mathrm{NPC}_{550}, \mathrm{NPC}_{700}$ morphologies show the shrinking phenomenon of $\mathrm{Zn}-\mathrm{MOF}$ during carbonization at this particular temperature (Figures S1 and S2). While the morphology retained from pristine MOF, brick, and rod shape at $600{ }^{\circ} \mathrm{C}$ (Figure 2d,e and Figure S3). The PXRD pattern of the NPC 800 sample showed two broad peaks of graphitic carbon at 23 (002) and $44^{\circ}$ (101) (Figure 2b) [7]. The absence of $\mathrm{ZnO}$ at higher carbonization temperature revealed when the temperature is close to its boiling point of $\mathrm{ZnO}\left(907^{\circ} \mathrm{C}\right)$ is reduced to $\mathrm{Zn}$ and evaporate.

Furthermore, the SEM revealed the morphology partially retained the pristine MOF with distorted graphitic carbon structures (Figure 2f, $g$ and Figure S4), TEM images noticeably show the presence of an abundant interconnected and oriented multilayer graphene domains can be observed (Figure 3a,b). Further, by increasing the temperature to $900{ }^{\circ} \mathrm{C}$, the PXRD pattern indicated a mixture of graphite oxide (GO) and graphitic carbon. A broad peak at $2 \theta \cong 12\left(\begin{array}{lll}0 & 0 & 1\end{array}\right)$ the reflection of graphite oxide, $23^{\circ}$ and $44^{\circ}$ crystallographic planes of graphitic carbon, which possess the amorphous carbon structure. SEM (Figure $2 \mathrm{~h}$ and Figure S5) and TEM (Figure $3 \mathrm{c}, \mathrm{d})$ images $\left(900^{\circ} \mathrm{C}\right)$ shown are revealed the pristine MOFs have fully or partially cracked the shapes and the shrinkage of the whole framework. 

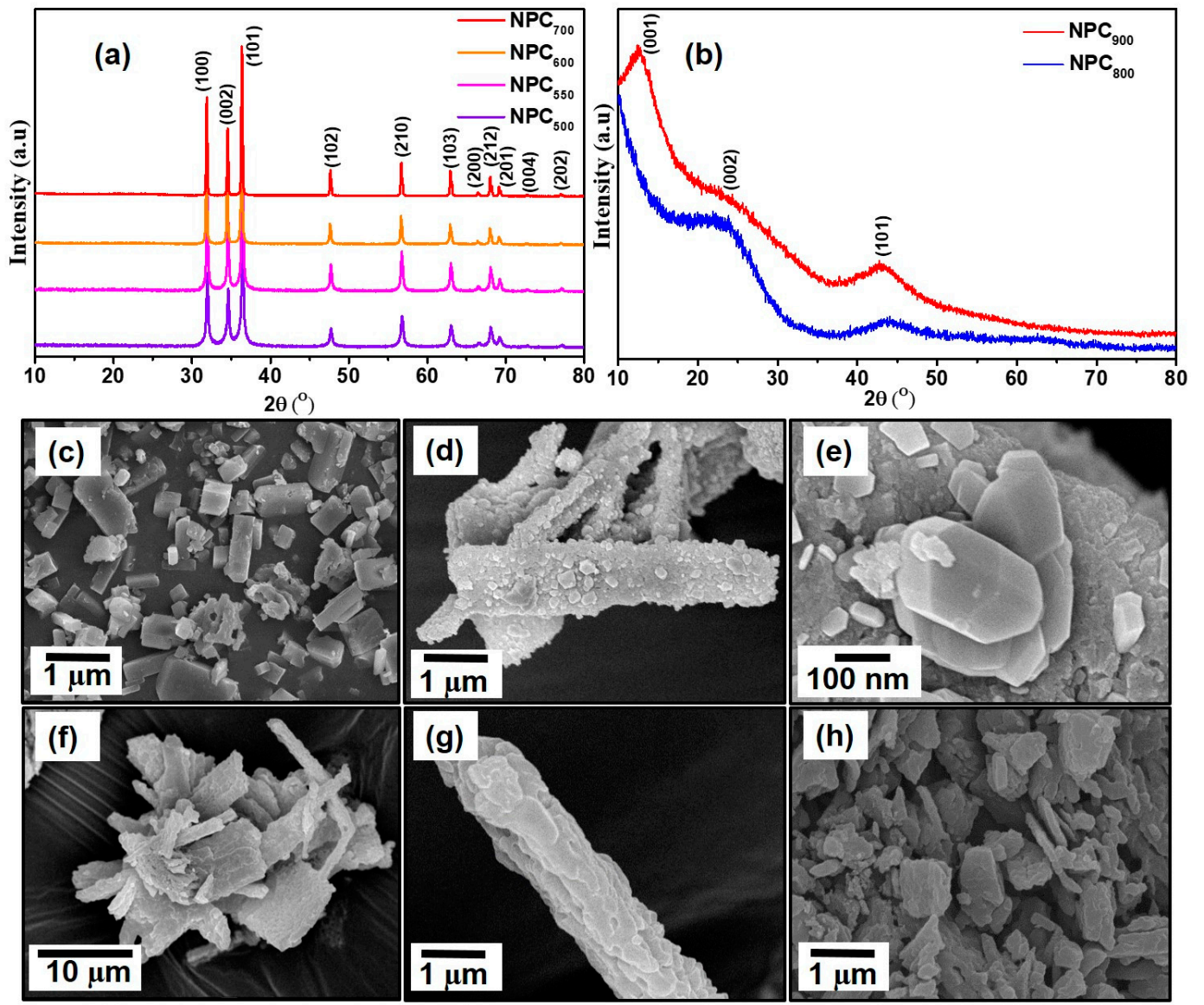

Figure 2. (a,b) PXRD patterns NPC samples. SEM images of, (c) synthesized Zn-MOF at the $1 \mu \mathrm{m}$ scale (before carbonization), (d-h) Zn-MOF after carbonization at different temperature. (d) $\mathrm{NPC}_{600}$ at the $1 \mu \mathrm{m}$ scale, (e) $\mathrm{NPC}_{600}$ at the $100 \mathrm{~nm}$ scale, (f) $\mathrm{NPC}_{800}$ at the $10 \mu \mathrm{m}$ scale, (g) NPC 800 at the $1 \mu \mathrm{m}$ scale and (h) NPC $_{900}$ at the $1 \mu \mathrm{m}$ scale.

Further, synthesized NPC materials were characterized by Raman spectroscopy for the degree of graphitization. The spectrum analyzed range between $1200 \mathrm{~cm}^{-1}$ to $1700 \mathrm{~cm}^{-1}$ bands were fitted with the spectra, $1180 \mathrm{~cm}^{-1}$ ( $\mathrm{A}_{1}$ band), $1340 \mathrm{~cm}^{-1}$ (D band), and $1600 \mathrm{~cm}^{-1}$ ( $\mathrm{G}$ band) [42]. Figure $\mathrm{S} 6$ shows significantly broadened D and $G$ bands. Gaussian fitting was used to separate the $A_{1}, D, G$ band and fitted after baseline subtraction. The $\mathrm{I}_{\mathrm{D}} / \mathrm{I}_{\mathrm{G}}$ ratio increased while increasing the temperature, indicating the formation of disorder with a low degree of graphitization of NPC materials was obtained. The $\mathrm{I}_{\mathrm{D}} / \mathrm{I}_{\mathrm{G}}$ ratio between $\mathrm{D}$ and $\mathrm{G}$ bands revealed the degree of graphitization in carbon-related materials. Temperature $500-700{ }^{\circ} \mathrm{C}$ carbonized materials obtained a higher degree of graphitization, due to the $\mathrm{ZnO}$ present in the carbon material. Because there is still a definite chemical interaction between $\mathrm{ZnO}$ and $\mathrm{N}$ atoms, the redshifts of the $\mathrm{D}$ bands by approximately $15 \mathrm{~cm}^{-1}$ to $\cong 1326$ were observed [43]. Further, as we increased the temperature $\left(800\right.$ and $\left.900^{\circ} \mathrm{C}\right), \mathrm{ZnO}-\mathrm{N}$ adducts were not detected and were also evidenced by PXRD. As the ratio is higher, it could be a low degree of graphitization, particularly those materials carbonized at $\geq 800{ }^{\circ} \mathrm{C}$ (see Table 1). The $\mathrm{G}$ band shifted to higher frequencies by approximately $6 \mathrm{~cm}^{-1}$ due to the nitrogen present in the NPC materials [44]. Chemical compositions of NPC were studied by ICP-MS and elemental analysis (Figure S7). The zinc contents were investigated by ICP-MS, increasing carbonization temperature results the decreasing zinc percentage are $51.7 \%$ $\left(600{ }^{\circ} \mathrm{C}\right), 43.72 \%\left(700{ }^{\circ} \mathrm{C}\right), 4.95 \%\left(800{ }^{\circ} \mathrm{C}\right), 0.26 \%\left(900{ }^{\circ} \mathrm{C}\right)$ and an appreciable amount of nitrogen (1.96-2.98 wt\%) based on elemental analysis. 

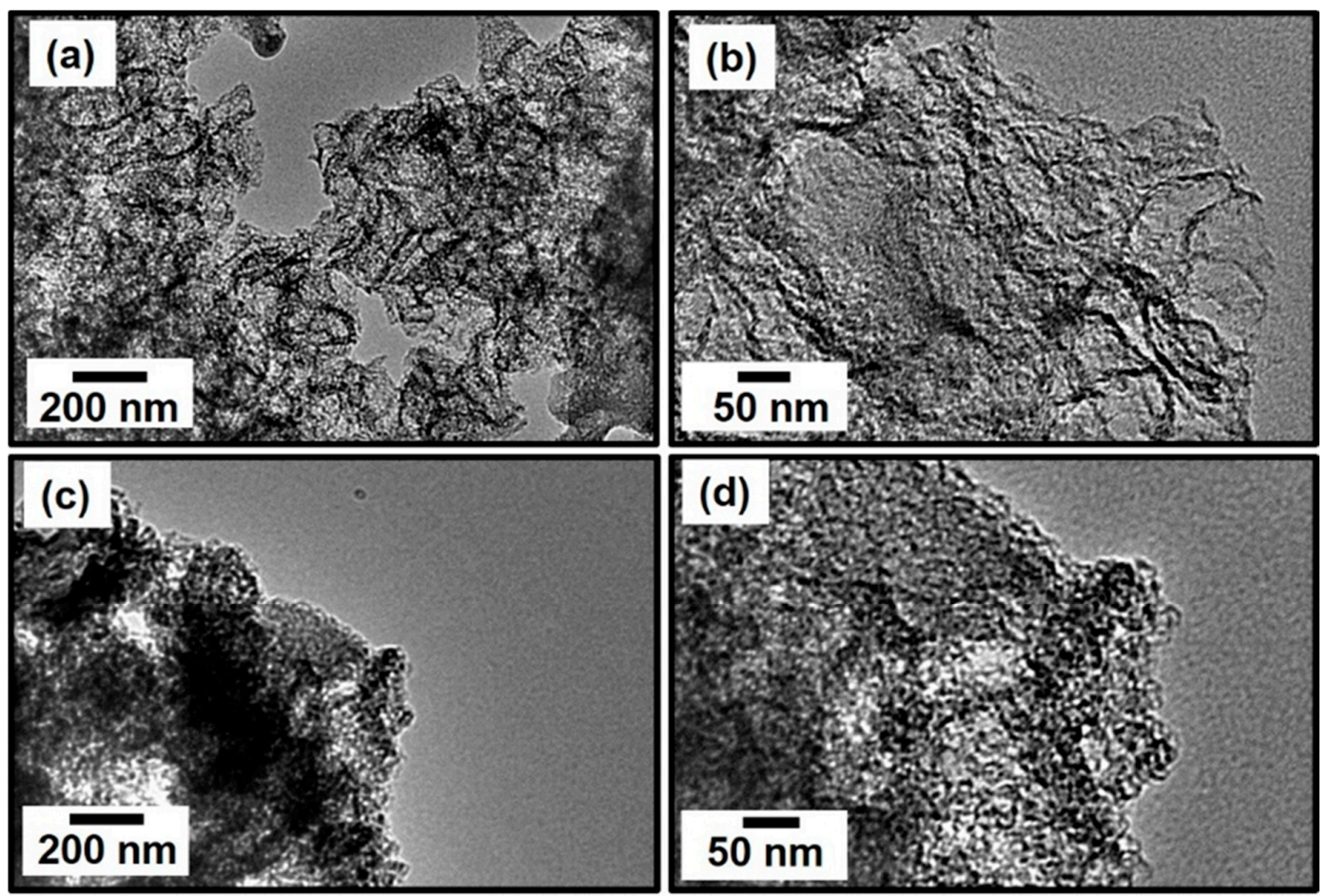

Figure 3. TEM images of (a) $\mathrm{NPC}_{800}$ at the $200 \mathrm{~nm}$ scale, (b) $\mathrm{NPC}_{800}$ at the $50 \mathrm{~nm}$ scale, (c) $\mathrm{NPC}_{900}$ at the $200 \mathrm{~nm}$ scale and (d) NPC 900 at the $50 \mathrm{~nm}$ scale.

Table 1. Surface and porous properties of the NPC samples.

\begin{tabular}{|c|c|c|c|c|c|c|}
\hline Sample & $\mathrm{I}_{\mathrm{D}} / \mathrm{I}_{\mathrm{G}}$ & $\begin{array}{l}\mathrm{S}_{\mathrm{BET}} a \\
\left(\mathrm{~m}^{2} / \mathrm{g}\right)\end{array}$ & $\begin{array}{l}\mathrm{V}_{\text {total }} b \\
\left(\mathrm{~cm}^{3} / \mathrm{g}\right)\end{array}$ & $\begin{array}{l}\mathrm{V}_{\text {micro }} c \\
\left(\mathrm{~cm}^{3} / \mathrm{g}\right)\end{array}$ & Pore Size (nm) & $\begin{array}{c}\mathrm{CO}_{2} \text { uptake }{ }^{d} \\
(\mathrm{mmol} / \mathrm{g})(\mathrm{wt} \%)\end{array}$ \\
\hline $\mathrm{NPC}_{500}$ & 0.92 & 273 & 0.18 & $0.09(50)$ & $0.75,1.4,2.1 \sim 3$ & $2.85(12.54)$ \\
\hline $\mathrm{NPC}_{550}$ & 0.98 & 287 & 0.20 & $0.091(45)$ & $0.75,1.4,2.1 \sim 3$ & $1.20(5.28)$ \\
\hline $\mathrm{NPC}_{600}$ & 1.01 & 289 & 0.22 & $0.094(42)$ & $0.75,1.4,2.1 \sim 3$ & $1.24(5.46)$ \\
\hline $\mathrm{NPC}_{700}$ & 1.07 & 296 & 0.22 & $0.10(45)$ & $0.89,1.4,2.1 \sim 3$ & $1.71(7.52)$ \\
\hline $\mathrm{NPC}_{800}$ & 1.24 & 1192 & 0.92 & $0.39(42)$ & $0.75,1.4,2.1 \sim 3$ & $4.71(20.72)$ \\
\hline $\mathrm{NPC}_{900}$ & 1.25 & 303 & 0.45 & $0.06(13)$ & $1.4,5-10$ & $2.51(11.04)$ \\
\hline
\end{tabular}

${ }^{a} \mathrm{~S}_{\mathrm{BET}}$ surface area was examined in the $\mathrm{P} / \mathrm{P}_{0}$ range of 0.01 to 0.1 , which gave the best linearity. ${ }^{b}$ Total pore volume at $\mathrm{P} / \mathrm{P}_{0}=0.99 .{ }^{c}$ Micropore volume $(\leq 2 \mathrm{~nm})$ and the values in asides are the percentage of the micropore volume relative to the total pore volume $\left(\mathrm{V}_{\text {micro }} / \mathrm{V}_{\text {total }}\right) .{ }^{d} \mathrm{CO}_{2}$ uptake at $273 \mathrm{~K}$ and 1 bar and the values in asides are weight percentage $(\mathrm{wt} \%)$.

\subsection{Porous Property and $\mathrm{CO}_{2}$ Uptake of NPC Materials}

The textural properties of these NPC materials were evaluated by the $\mathrm{N}_{2}$ sorption analyzer. The Figure $4 \mathrm{a}-\mathrm{c}$ represented the $\mathrm{N}_{2}$ uptake isotherm and corresponding pore sizes of the NPC materials. Table 1 represents the NPC material's surface area, pore volume and pore size. The $\mathrm{N}_{2}$ sorption curves of the NPC materials possess type-I isotherms that steeply climb in the low-pressure range $\left(\mathrm{P} / \mathrm{P}_{0}=0-0.10\right)$, suggesting that micropores were dominant [45]. In the high-pressure range $\left(\mathrm{P} / \mathrm{P}_{0}=0.40-1.00\right)$, there were decent increases in the adsorption in all samples and a slight hysteresis loop between the sorption curves, which revealed that mesopores were also present in the materials. The surface area and total pore volume of the $\mathrm{NPC}_{500-700}$ materials is nearly equal to 273, 287, 289, 296 $\mathrm{m}^{2} / \mathrm{g}$ and $0.18,0.20,0.22,0.22 \mathrm{~cm}^{3} / \mathrm{g}$ correspondingly (see Table 1 ). 

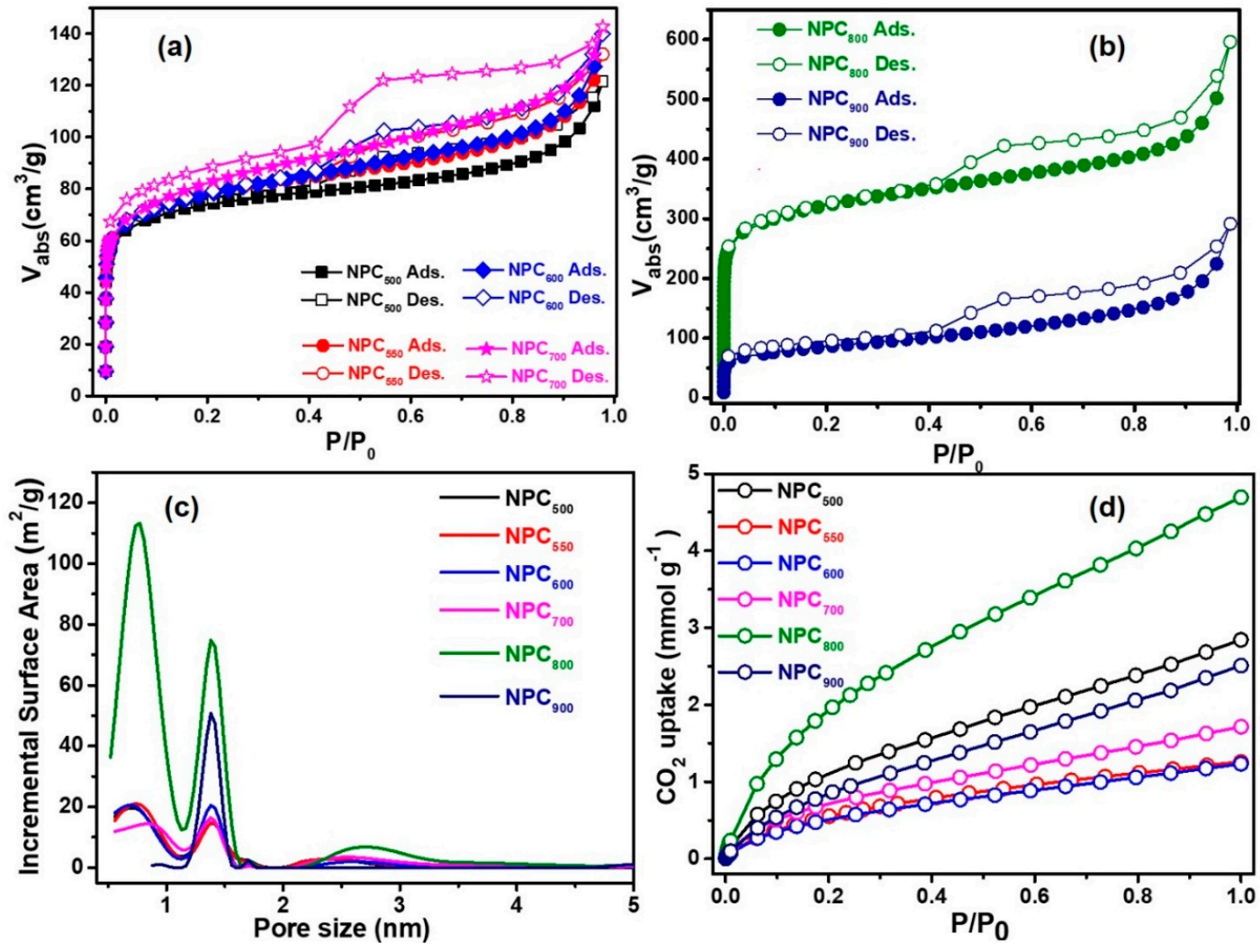

Figure 4. (a,b) $\mathrm{N}_{2}$ sorption analysis at $77 \mathrm{~K}$, (c) NLDFT pore size distribution profile and (d) $\mathrm{CO}_{2}$ sorption isotherm at $273 \mathrm{~K}$ and 1 bar of NPC materials.

Whereas the BET surface area of the $\mathrm{NPC}_{800}$ material has $1192 \mathrm{~m}^{2} / \mathrm{g}$ and a total pore volume 0.92 $\mathrm{cm}^{3} / \mathrm{g}$. The majority of the pores of $\mathrm{NPC}_{500-800}$ materials are $0.75,1.4 \mathrm{~nm}$ retained from the pristine MOF (Figure 4c), while there are mesopores around 2.1-3 nm, which specifies the occurrence of mesopores in the NPC materials (Figures S8-S13). While the NPC 900 materials show a lesser surface area (303 $\left.\mathrm{m}^{2} / \mathrm{g}\right)$, pore volume $\left(0.45 \mathrm{~cm}^{3} / \mathrm{g}\right)$ indicates framework shrinkage and fragmentation throughout the high-temperature carbonization process. The total pore volume of $\mathrm{NPC}_{800}$ material has a better percentage than the $\mathrm{NPC}_{500-700}$ and $\mathrm{NPC}_{900}$ materials. It is noted that the $\mathrm{NPC}_{800}$ material reached $42 \%$ of micropores, whereas, the percentage of $\mathrm{V}_{\text {micro }} / \mathrm{V}_{\text {total }}$ decreased significantly to $13 \%$ in the $\mathrm{NPC}_{900}$ sample. $\mathrm{CO}_{2}$ sorption is investigated for the NPC materials at $273 \mathrm{~K}$ at 1 bar (Figure $4 \mathrm{~d}$ ). $\mathrm{NPC}_{800}$ demonstrated a higher $\mathrm{CO}_{2}$ capture of $4.71 \mathrm{mmol} / \mathrm{g}$ than $\mathrm{NPC}_{500}(2.85 \mathrm{mmol} / \mathrm{g}), \mathrm{NPC}_{550}(1.20 \mathrm{mmol} / \mathrm{g})$, $\mathrm{NPC}_{600}(1.24 \mathrm{mmol} / \mathrm{g}), \mathrm{NPC}_{700}(1.71 \mathrm{mmol} / \mathrm{g})$ and NPC $900(2.51 \mathrm{mmol} / \mathrm{g})$ at $273 \mathrm{~K}$ and 1 bar. Such a micro-mesoporous structure of $\mathrm{NPC}_{800}$ material provides a fast diffusion of $\mathrm{CO}_{2}$ into the inner pores material. $\mathrm{NPC}_{800}$ material showed $\mathrm{CO}_{2}$ capacity value closely matches/ greater than those of the carbon-related materials (see Table S1).

\subsection{Comparisons Voltammetric Behavior of Various SPCE/NPC Modified Electrode in FeCN}

$\mathrm{CV}$ analysis was executed to study the electrochemical behavior of SPCE and SPCE/NPC modified electrodes in $5 \mathrm{mM} \mathrm{FeCN}$ under a potential window from -0.2 to $+0.6 \mathrm{~V}$. As can be seen in Figure 5, bare SPCE exhibit a well-defined reversible redox peak at $\mathrm{E}^{\circ}=+193 \mathrm{mV}$ with a peak to peak potential difference $(\triangle \mathrm{Ep}=\mathrm{Epa}-\mathrm{Epc})$ value of $126 \mathrm{mV}$, which is the characteristic peak for $\mathrm{Fe}^{2+} / \mathrm{Fe}^{3+}$ interconversion [46,47]. After SPCE/NPC modification, relatively higher/lower redox current responses were noticed with a $\Delta \mathrm{Ep}$ value of about 561, 235, 125, 112, 137 and $140 \mathrm{mV}$, while the relative current change $(\triangle \mathrm{Ia})$ was recorded for $\mathrm{SPCE} / \mathrm{NPC}_{500}, \mathrm{SPCE} / \mathrm{NPC}_{550}, \mathrm{SPCE} / \mathrm{NPC} 600$, $\mathrm{SPCE} / \mathrm{NPC}_{700}, \mathrm{SPCE} / \mathrm{NPC}_{800}, \mathrm{SPCE} / \mathrm{NPC}_{900}$ of about $-99,-88,-29,-12,+83$ and $+113 \mu \mathrm{A}$, respectively. 
The observation is due to the semiconductor $\mathrm{Zn}$ moieties existing up to a carbonization temperature of $700{ }^{\circ} \mathrm{C}$ that results in a decrease in FeCN signal. In contrary, carbonization at 800 and $900{ }^{\circ} \mathrm{C}$ produced relatively smaller Zn moieties with NPC and hence an increase in signal. This result suggests that the semiconductor $\mathrm{Zn}$ content decreased with increasing carbonization temperature. In other words, the FeCN current response is inversely proportional to the $\mathrm{Zn}$ content. The obtained results coincide with the elemental analysis, ICP-MS and PXRD results.

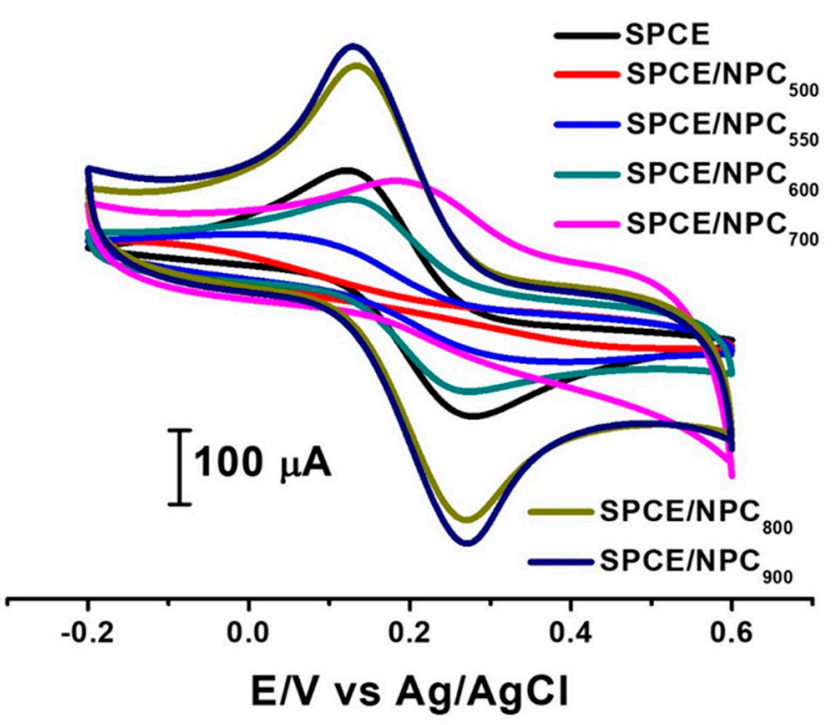

Figure 5. Cyclic voltammetric response of $\mathrm{SPCE}$ and $\mathrm{SPCE} / \mathrm{NPC}_{\mathrm{T}}$ in $5 \mathrm{mM}$ ferric cyanide solution.

\subsection{Detection of $\mathrm{H}_{2} \mathrm{O}_{2}$ at SPCE/NPC}

The surface area and porous defective sites have an important role in the electrochemical sensors. Therefore, $\mathrm{H}_{2} \mathrm{O}_{2}$ sensing applicability was tested for SPCE/NPC $500, \mathrm{SPCE}_{\mathrm{NPC}} \mathrm{N50}_{2}, \mathrm{SPCE}_{\mathrm{NPC}} \mathrm{N}_{600}$, $\mathrm{SPCE}_{\mathrm{NPC}} \mathrm{N00}, \mathrm{SPCE}_{\mathrm{NPC}} \mathrm{S00}, \mathrm{SPCE} / \mathrm{NPC}_{900}$, respectively. Figure 6 shows electro catalytic reduction $\mathrm{CVs}$ of $\mathrm{H}_{2} \mathrm{O}_{2}$ at various $\mathrm{SPCE} / \mathrm{NPC}_{\mathrm{T}}$ electrodes. $\mathrm{CV}$ measurements were done in $0.1 \mathrm{M}, \mathrm{pH} 7.4 \mathrm{~PB}$ solution under the potential sweeping from 0 to $-1.2 \mathrm{~V}$ at a scan rate of $100 \mathrm{mV} \mathrm{s}^{-1}$. During the cathodic segment, $\mathrm{H}_{2} \mathrm{O}_{2}$ reduction peak [48] was noticed at - $0.7 \mathrm{~V}$ for SPCE and for SPCE/NPC $\mathrm{T}_{\mathrm{T}}$ the same reduction peak was noticed with lower over potential $(\sim-0.4 \mathrm{~V})$. Among the various electrodes, detection response are clearer and more explicit at $\mathrm{SPCE} / \mathrm{NPC}_{600}$. These results evidently exposed that the SPCE/NPC600 electrode exhibited better electrocatalytic $\mathrm{H}_{2} \mathrm{O}_{2}$ reduction than other electrodes. Therefore, $\mathrm{SPCE} / \mathrm{NPC}_{600}$ was chosen for further studies. 

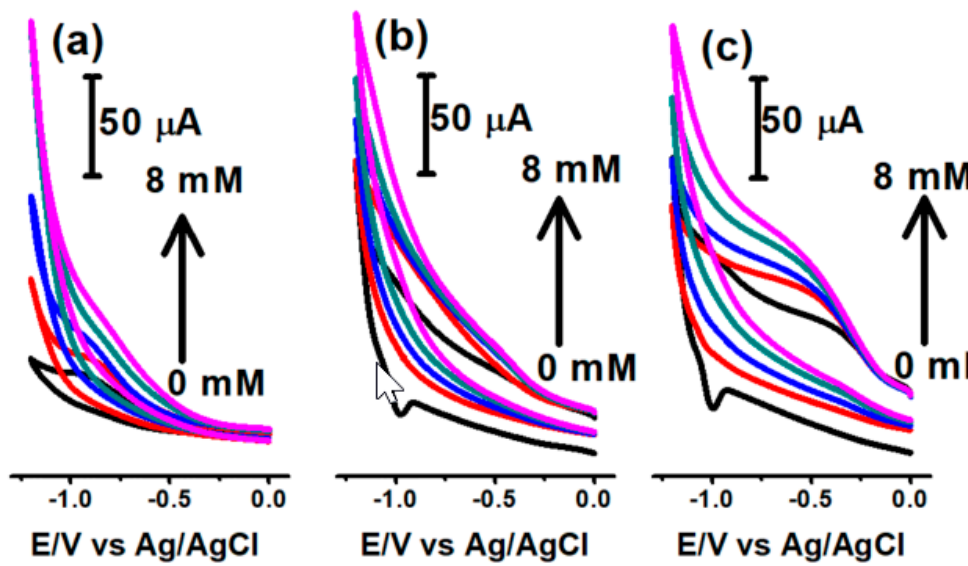

(d)
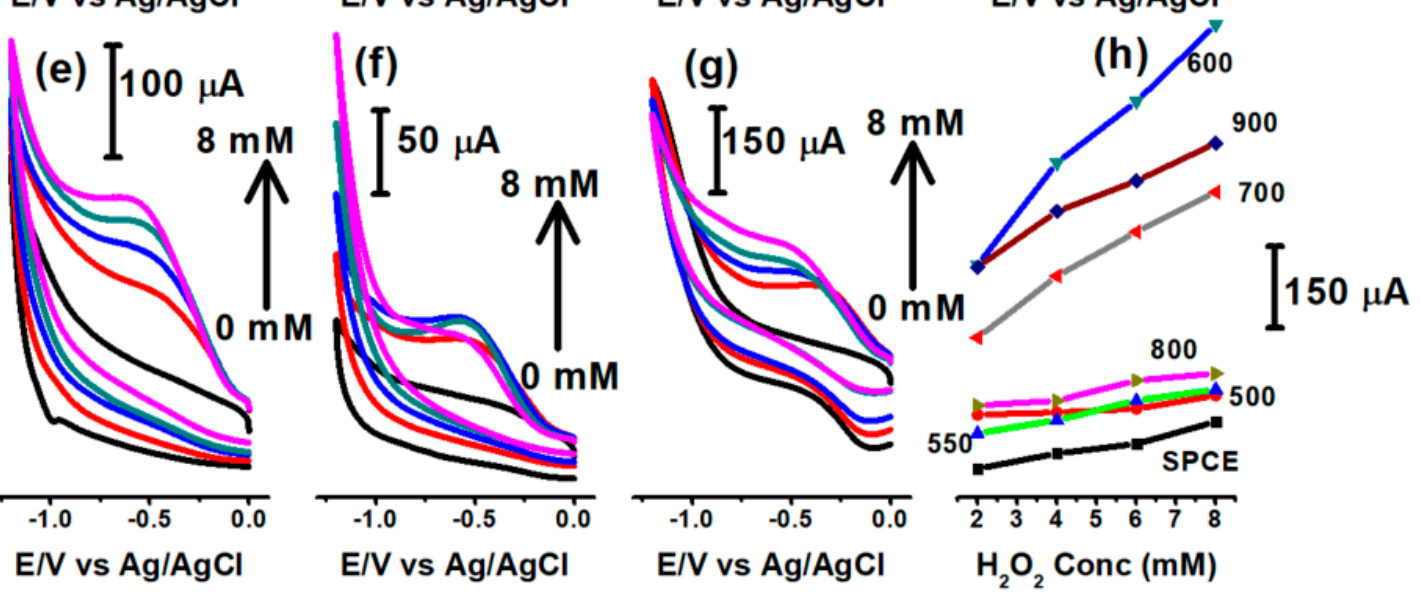

Figure 6. Cyclic voltammetric detection of $\mathrm{H}_{2} \mathrm{O}_{2}$ in $0.1 \mathrm{M}, \mathrm{pH} 7 \mathrm{~PB}$ (a) SPCE, (b) SPCE/NPC 500 , (c), SPCE/NPC 550, (d) SPCE/NPC $_{600}$, (e) SPCE/NPC 700, (f) SPCE/NPC 800 and (g) SPCE/NPC 900 , respectively.

(h) Their corresponding current verses concentration plots.

\subsection{Flow Injection Analysis (FIA) Detection of $\mathrm{H}_{2} \mathrm{O}_{2}$ at SPCE/NPC 600}

The above observation was further utilized for amperometric FIA analysis of $\mathrm{H}_{2} \mathrm{O}_{2}$. The $\mathrm{H}_{2} \mathrm{O}_{2}$ reduction current increased linearly with increasing concentration, in which $\mathrm{H}_{2} \mathrm{O}_{2}$ was electrochemically reduced at $-0.4 \mathrm{~V}$ by applying a potential, and thus yielded quantitative current responses corresponding to the content of $\mathrm{H}_{2} \mathrm{O}_{2}$ (Figure 7). A wide linearity range between $100 \mu \mathrm{M}$ and $10 \mathrm{mM}$ with a $\mathrm{R}^{2}$ value of 0.9865 and a limit of detection (LOD) $27.5 \mu \mathrm{M}$ were obtained. In order to access the repeatability of a SPCE/NPC 600 modified electrode, 12 repeated injections of $0.5 \mathrm{mM} \mathrm{H}_{2} \mathrm{O}_{2}$ were performed and a RSD value of $4.13 \%$ was obtained. Compared to a few other $\mathrm{Zn}$ based $\mathrm{H}_{2} \mathrm{O}_{2}$ sensors (Table S2), the present method exhibited a wide linear range along with a specific sensitivity of $108.7 \mu \mathrm{A} \mathrm{mM}^{-1} \mathrm{~cm}^{-2}$. 

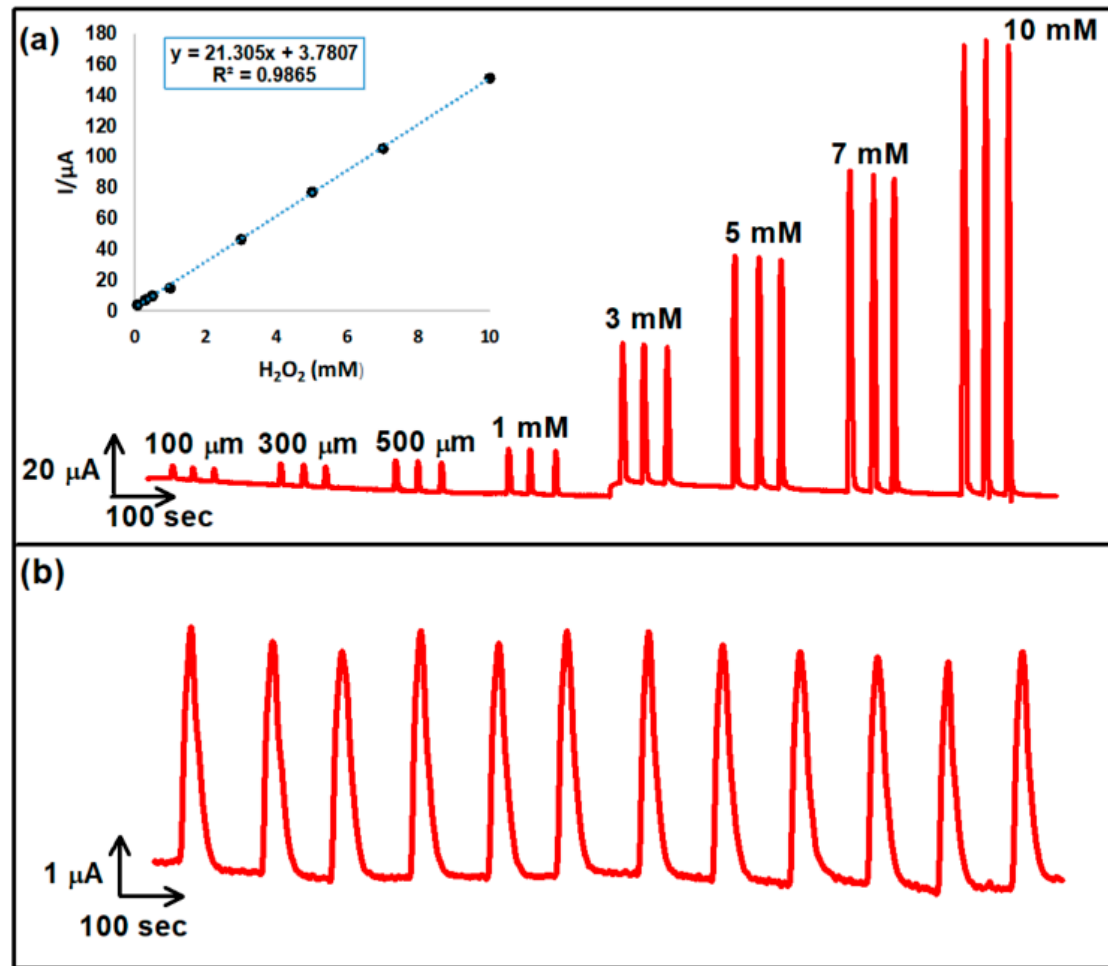

Figure 7. (a) Detection of $\mathrm{H}_{2} \mathrm{O}_{2}$ by FIA method at $\mathrm{SPCE} / \mathrm{NPC}_{600}$, (b) FIA responses of 12 continuous injections of $0.5 \mathrm{mM} \mathrm{H}_{2} \mathrm{O}_{2}$.

\section{Conclusions}

Herein, we reported the synthesized NPC materials at various carbonization temperatures at a constant time under a $\mathrm{N}_{2}$ atmosphere. NPC materials surface, morphology, chemical composition, porous properties where characterized by PXRD, SEM, TEM, Raman spectroscopy, ICP-MS, elemental analysis, and $77 \mathrm{~K} \mathrm{~N}_{2}$ sorption isotherms. Pristine MOF pore size was tuned to the porous carbon material, such an ultramicropore, micropore and mesopore combined in unique material and interaction between $\mathrm{ZnO}$ to NPC to give the pathway to synthesize the effective electrochemical property and $\mathrm{CO}_{2}$ sorption materials. These combinations in $\mathrm{NPC}_{800}$ exhibited a higher $\mathrm{CO}_{2}$ uptake of $4.71 \mathrm{mmol}$ $\mathrm{g}^{-1}$ compare to other $\mathrm{NPC}_{\mathrm{T}}$ materials. $\mathrm{NPC}_{600}$ displayed a good electrochemical reduction towards $\mathrm{H}_{2} \mathrm{O}_{2}$. Under optimal conditions, our sensor exhibited linearity that ranged from $0.1-10 \mathrm{mM}$, which confirmed its sensitive response to $\mathrm{H}_{2} \mathrm{O}_{2}$ over a wide range of concentrations. The detection limit was determined to be $27.5 \mu \mathrm{M}(\mathrm{S} / \mathrm{N}=3)$

Supplementary Materials: The following are available online at http://www.mdpi.com/1996-1944/13/2/264/s1, Figure S1. SEM image of (a) NPC 500 and (b) NPC 550 . Figure S2. SEM image of $\mathrm{NPC}_{700}(\mathrm{a}, \mathrm{b})$. Figure S3. SEM images of $\mathrm{NPC}_{600}(\mathrm{a}-\mathrm{d})$. Figure S4. SEM image of NPC $800(\mathrm{a}-\mathrm{d})$. Figure S5. SEM image of $\mathrm{NPC}_{900}(\mathrm{a}-\mathrm{d})$. Figure S6. Raman spectra of the obtained NPC materails. (a) $\mathrm{NPC}_{500}$, (b) $\mathrm{NPC}_{550}$, (c) $\mathrm{NPC}_{600}$, (d) $\mathrm{NPC}_{700}$, (e) $\mathrm{NPC}_{800}$ and (f) NPC 900 . Figure S7. Relative atom percentage at different carbonization temperature (600-900 $\left.{ }^{\circ} \mathrm{C}\right)$. Figure S8. NLDFT pore size distribution profile for NPC 500 . Figure S9. NLDFT pore size distribution profile for $\mathrm{NPC}_{550}$. Figure S10. NLDFT pore size distribution profile for $\mathrm{NPC}_{600}$. Figure S11. NLDFT pore size distribution profile for $\mathrm{NPC}_{700}$. Figure S12. NLDFT pore size distribution profile for $\mathrm{NPC}_{800}$. Figure S13. NLDFT pore size distribution profile for NPC 900 . Table S1. Comparison of $\mathrm{CO}_{2}$ uptake with previously reported carbon related materials and MOF-derived carbon materials at temperature 273K in 1 bar. Table S2. Comparison of $\mathrm{Zn}$ electrode-based $\mathrm{H}_{2} \mathrm{O}_{2}$ sensors with previously reported $\mathrm{ZnO} /$ carbon related materials.

Author Contributions: K.S. and C.-H.L. conceived and designed the experiments; K.S. and M.T. performed the experiments, analyzed the data; K.S., M.T., and S.P. wrote the paper; C.-H.L. contributed reagents/materials/analysis tools. All authors have read and agreed to the published version of the manuscript.

Funding: Financial support received from the Ministry of Science and Technology, Taiwan (MOST107-2628-M-003-005-MY3 and MOST107-2113-M-003-017-MY2) are gratefully acknowledged. 
Conflicts of Interest: The authors declare no conflicts of interest.

\section{References}

1. Jiang, H.L.; Liu, B.; Lan, Y.Q.; Kuratani, K.; Akita, T.; Shioyama, H.; Zong, F.Q.; Xu, Q. From Metal-Organic Framework to Nanoporous Carbon: Toward a Very High Surface Area and Hydrogen Uptake. J. Am. Chem. Soc. 2011, 133, 11854-11857. [CrossRef] [PubMed]

2. Yang, S.J.; Kim, T.; Im, J.H.; Kim, Y.S.; Lee, K.; Jung, H.; Park, C.R. MOF-Derived Hierarchically Porous Carbon with Exceptional Porosity and Hydrogen Storage Capacity. Chem. Mater. 2012, 24, 464-470. [CrossRef]

3. Khan, I.A.; Badshah, A.; Khan, I.; Zhao, D.; Nadeem, M.A. Soft-template carbonization approach of MOF-5 to mesoporous carbon nanospheres as excellent electrode materials for supercapacitor. Microporous Mesoporous Mater. 2017, 253, 169-176. [CrossRef]

4. Chaikittisilp, W.; Ariga, K.; Yamauchi, Y. A new family of carbon materials: Synthesis of MOF-derived nanoporous carbons and their promising applications. J. Mater. Chem. A 2013, 1, 14-19. [CrossRef]

5. Ling, P.; Hao, Q.; Lei, J.; Ju, H. Porphyrin functionalized porous carbon derived from metal-organic framework as a biomimetic catalyst for electrochemical biosensing. J. Mater. Chem. B 2015, 3, 1335-1341. [CrossRef]

6. Proietti, E.; Jaouen, F.; Lefevre, M.; Larouche, N.; Tian, J.; Herranz, J.; Dodelet, J.P. Iron-based cathode catalyst with enhanced power density in polymer electrolyte membrane fuel cells. Nat. Commun. 2011, 2, 416. [CrossRef]

7. Liu, B.; Shioyama, H.; Jiang, H.; Zhang, X.; Xu, Q. Metal-organic framework (MOF) as a template for syntheses of nanoporous carbons as electrode materials for supercapacitor. Carbon 2010, 48, 456-463. [CrossRef]

8. Khan, I.A.; Badshah, A.; Nadeem, M.A.; Haider, N.; Nadeem, M.A. A copper based metal-organic framework as single source for the synthesis of electrode materials for high-performance supercapacitors and glucose sensing applications. Int. J. Hydrog. Energy 2014, 39, 19609-19620. [CrossRef]

9. Khan, I.A.; Qian, Y.; Badshah, A.; Nadeem, M.A.; Zhao, D. Highly Porous Carbon Derived from MOF-5 as a Support of ORR Electrocatalysts for Fuel Cells. ACS Appl. Mater. Interfaces 2016, 8, 17268-17275. [CrossRef]

10. Khan, I.A.; Badshah, A.; Nadeem, M.A. Single step pyrolytic conversion of zeolitic imidazolate to CoO encapsulated $\mathrm{N}$-doped carbon nanotubes as an efficient oxygen reduction electrocatalyst. Catal. Commun. 2017, 99, 10-14. [CrossRef]

11. Wang, L.; Xu, Q.; Xu, J.; Weng, J. Synthesis of hybrid nanocomposites of ZIF-8 with two-dimensional black phosphorus for photocatalysis. RSC Adv. 2016, 6, 69033-69039. [CrossRef]

12. Wei, X.; Zhang, Z.; Qin, L.; Dai, J. Template-free preparation of yeast-derived three-dimensional hierarchical porous carbon for highly efficient sulfamethazine adsorption from water. J. Taiwan Inst. Chem. E 2018. [CrossRef]

13. Wei, L.; Tian, K.; Jin, Y.; Zhang, X.; Guo, X. Three-dimensional porous hollow microspheres of activated carbon for high-performance electrical double-layer capacitors. Microporous Mesoporous Mater. 2016, 227, 210-218. [CrossRef]

14. Li, Y.; Xu, R.; Wang, X.; Wang, B.; Cao, J.; Yang, J.; Wei, J. Waste wool derived nitrogen-doped hierarchical porous carbon for selective $\mathrm{CO}_{2}$ capture. RSC Adv. 2018, 8, 19818-19826. [CrossRef]

15. Estevez, L.; Barpaga, D.; Zheng, J.; Sabale, S.; Patel, R.L.; Zhang, J.-G.; McGrail, B.P.; Motkuri, R.K. Hierarchically Porous Carbon Materials for $\mathrm{CO}_{2}$ Capture: The Role of Pore Structure. Ind. Eng. Chem. Res. 2018, 57, 1262-1268. [CrossRef]

16. Zhang, Y.; Li, B.; Williams, K.; Gao, W.Y.; Ma, S. A new microporous carbon material synthesized via thermolysis of a porous aromatic framework embedded with an extra carbon source for low-pressure $\mathrm{CO}_{2}$ uptake. Chem. Commun. 2013, 49, 10269-10271. [CrossRef]

17. Oschatz, M.; Antonietti, M. A search for selectivity to enable $\mathrm{CO}_{2}$ capture with porous adsorbents. Energy Environ. Sci. 2018, 11, 57-70. [CrossRef]

18. Liu, J.; Wang, X.; Gao, J.; Zhang, Y.; Lu, Q.; Liu, M. Hollow porous carbon spheres with hierarchical nanoarchitecture for application of the high performance supercapacitors. Electrochim. Acta 2016, 211, 183-192. [CrossRef]

19. Geng, W.; Ma, F.; Wu, G.; Song, S.; Wan, J.; Ma, D. MgO-templated hierarchical porous carbon sheets derived from coal tar pitch for supercapacitors. Electrochim. Acta 2016, 191, 854-863. [CrossRef] 
20. Kim, H.R.; Yoon, T.-U.; Kim, S.-I.; An, J.; Bae, Y.-S.; Lee, C.Y. Beyond pristine MOFs: Carbon dioxide capture by metal-organic frameworks (MOFs)-derived porous carbon materials. RSC Adv. 2017, 7, 1266-1270. [CrossRef]

21. He, Y.; Chen, F.; Li, B.; Qian, G.; Zhou, W.; Chen, B. Porous metal-organic frameworks for fuel storage. Coord. Chem. 2018, 373, 167-198. [CrossRef]

22. Lin, R.-B.; Xiang, S.; Xing, H.; Zhou, W.; Chen, B. Exploration of porous metal-organic frameworks for gas separation and purification. Coord. Chem. 2019, 378, 87-103. [CrossRef]

23. Du, W.; Bai, Y.-L.; Xu, J.; Zhao, H.; Zhang, L.; Li, X.; Zhang, J. Advanced metal-organic frameworks (MOFs) and their derived electrode materials for supercapacitors. J. Power Sources 2018, 402, 281-295. [CrossRef]

24. Wen, Y.; Zhang, J.; Xu, Q.; Wu, X.-T.; Zhu, Q.-L. Pore surface engineering of metal-organic frameworks for heterogeneous catalysis. Coord. Chem. 2018, 376, 248-276. [CrossRef]

25. Müller-Buschbaum, K.; Beuerle, F.; Feldmann, C. MOF based luminescence tuning and chemical/physical sensing. Microporous Mesoporous Mater. 2015, 216, 171-199. [CrossRef]

26. Nadar, S.S.; Rathod, V.K. Magnetic-metal organic framework (magnetic-MOF): A novel platform for enzyme immobilization and nanozyme applications. Int. J. Biol. Macromol. 2018. [CrossRef]

27. Torad, N.L.; Hu, M.; Kamachi, Y.; Takai, K.; Imura, M.; Naito, M.; Yamauchi, Y. Facile synthesis of nanoporous carbons with controlled particle sizes by direct carbonization of monodispersed ZIF-8 crystals. Chem. Commun. 2013, 49, 2521-2523. [CrossRef]

28. Aijaz, A.; Sun, J.K.; Pachfule, P.; Uchida, T.; Xu, Q. From a metal-organic framework to hierarchical high surface-area hollow octahedral carbon cages. Chem. Commun. 2015, 51, 13945-13948. [CrossRef]

29. Chen, J.J.; Chen, Y.T.; Senthil Raja, D.; Kang, Y.H.; Tseng, P.C.; Lin, C.H. Carbonization and oxidation of metal-organic frameworks based on 1,4-naphthalene dicarboxylates. Sci. Technol. Adv. Mater. 2015, 16. [CrossRef]

30. Chen, J.J.; Chen, Y.T.; Raja, D.S.; Kang, Y.H.; Tseng, P.C.; Lin, C.H. Metal-Organic Frameworks to Metal/Metal Oxide Embedded Carbon Matrix: Synthesis, Characterization and Gas Sorption Properties. Materials 2015, 8 , 5336-5347. [CrossRef]

31. Sivasankar, K.; Devasenathipathy, R.; Wang, S.-F.; Kohila rani, K.; Raja, D.S.; Lin, C.-H. Synthesis of hierarchical mesoporous graphite oxide/ $\mathrm{Al}_{2} \mathrm{O}_{3}$ from $\mathrm{MIL}-100(\mathrm{Al})$ for the electrochemical determination of caffeic acid in red wine samples. J. Taiwan Inst. Chem. E 2018, 84, 188-195. [CrossRef]

32. Sivasankar, K.; Rani, K.K.; Wang, S.F.; Devasenathipathy, R.; Lin, C.H. Copper Nanoparticle and Nitrogen Doped Graphite Oxide Based Biosensor for the Sensitive Determination of Glucose. Nanomaterials 2018, 8 , 429. [CrossRef] [PubMed]

33. Song, Y.; Cho, D.; Venkateswarlu, S.; Yoon, M. Systematic study on preparation of copper nanoparticle embedded porous carbon by carbonization of metal-organic framework for enzymatic glucose sensor. RSC Adv. 2017, 7, 10592-10600. [CrossRef]

34. Bai, Z.; Dong, W.; Ren, Y.; Zhang, C.; Chen, Q. Preparation of Nano Au and Pt Alloy Microspheres Decorated with Reduced Graphene Oxide for Nonenzymatic Hydrogen Peroxide Sensing. Langmuir 2018, 34, 2235-2244. [CrossRef] [PubMed]

35. Selvaraj, B.; Jen-Lin, C.; Jyh-Myng, Z. Extremely Stable Copper-Polymelamine Composite Material for Amperometric Hydrogen Peroxide Sensing. J. Polym. Sci. 2013, 51, 1639-1646. [CrossRef]

36. Qinglin, S.; Xiujuan, Q.; Jianbin, Z. The Hybrid of Gold Nanoparticles and 3D Flower-like MnO2 Nanostructure with Enhanced Activity for Detection of Hydrogen Peroxide. Electroanalysis 2018, 30, 137-145. [CrossRef]

37. Wang, J.; $\mathrm{Xu}, \mathrm{M} . ; \mathrm{Zhao,} \mathrm{R}$; Chen, G. A highly sensitive $\mathrm{H}_{2} \mathrm{O}_{2}$ sensor based on zinc oxide nanorod arrays film sensing interface. Analyst 2010, 135, 1992-1996. [CrossRef]

38. Al-Hardan, N.H.; Abdul Hamid, M.A.; Shamsudin, R.; Othman, N.K.; Kar Keng, L. Amperometric Non-Enzymatic Hydrogen Peroxide Sensor Based on Aligned Zinc Oxide Nanorods. Sensors 2016, 16, 1004. [CrossRef]

39. Chaemchuen, S.; Zhou, K.; Kabir, N.A.; Chen, Y.; Ke, X.; Van Tendeloo, G.; Verpoort, F. Tuning metal sites of DABCO MOF for gas purification at ambient conditions. Microporous Mesoporous Mater. 2015, 201, 277-285. [CrossRef]

40. Qadir, N.U.; Said, S.A.M.; Bahaidarah, H.M. Structural stability of metal organic frameworks in aqueous media-Controlling factors and methods to improve hydrostability and hydrothermal cyclic stability. Microporous Mesoporous Mater. 2015, 201, 61-90. [CrossRef] 
41. Tarlani, A.; Fallah, M.; Lotfi, B.; Khazraei, A.; Golsanamlou, S.; Muzart, J.; Mirza-Aghayan, M. New ZnO nanostructures as non-enzymatic glucose biosensors. Biosens. Bioelectron. 2015, 67, 601-607. [CrossRef] [PubMed]

42. Gong, Y.-T.; Li, B.-H.; Pei, T.; Lin, C.-H.; Lee, S. Raman investigation on carbonization process of metal-organic frameworks. J. Raman Spectrosc. 2016, 47, 1271-1275. [CrossRef]

43. Gadipelli, S.; Guo, Z.X. Tuning of ZIF-Derived Carbon with High Activity, Nitrogen Functionality, and Yield-A Case for Superior $\mathrm{CO}_{2}$ Capture. ChemSusChem 2015, 8, 2123-2132. [CrossRef] [PubMed]

44. Zhang, C.; Fu, L.; Liu, N.; Liu, M.; Wang, Y.; Liu, Z. Synthesis of nitrogen-doped graphene using embedded carbon and nitrogen sources. Adv. Mater. 2011, 23, 1020-1024. [CrossRef]

45. Gomez-Gualdron, D.A.; Moghadam, P.Z.; Hupp, J.T.; Farha, O.K.; Snurr, R.Q. Application of Consistency Criteria to Calculate BET Areas of Micro- and Mesoporous Metal-Organic Frameworks. J. Am. Chem. Soc. 2016, 138, 215-224. [CrossRef]

46. Thiruppathi, M.; Thiyagarajan, N.; Gopinathan, M.; Chang, J.-L.; Zen, J.-M. A dually functional 4-aminophenylboronic acid dimer for voltammetric detection of hypochlorite, glucose and fructose. Microchim. Acta 2017, 184, 4073-4080. [CrossRef]

47. Zen, J.-M.; Tsai, D.-M.; Senthil Kumar, A. Flow Injection Analysis of Ascorbic Acid in Real Samples Using a Highly Stable Chemically Modified Screen-Printed Electrode. Electroanalysis 2003, 15, 1171-1176. [CrossRef]

48. Thiruppathi, M.; Lin, P.-Y.; Chou, Y.-T.; Ho, H.-Y.; Wu, L.-C.; Ho, J.-A.A. Simple aminophenol-based electrochemical probes for non-enzymatic, dual amperometric detection of NADH and hydrogen peroxide. Talanta 2019, 200, 450-457. [CrossRef]

(C) 2020 by the authors. Licensee MDPI, Basel, Switzerland. This article is an open access article distributed under the terms and conditions of the Creative Commons Attribution (CC BY) license (http://creativecommons.org/licenses/by/4.0/). 